DOE/NETL-2000/1123

\title{
LIMB Demonstration Project Extension and Coolside Demonstration: A DOE Assessment
}

April 2000

U.S. Department of Energy

National Energy Technology Laboratory

P.O. Box 880, 3610 Collins Ferry Road

Morgantown, WV 26507-0880

and

P.O. Box 10940, 626 Cochrans Mill Road

Pittsburgh, PA 15236-0940 


\section{Disclaimer}

This report was prepared as an account of work sponsored by an agency of the United States Government. Neither the United States Government nor any agency thereof, nor any of their employees, makes any warranty, express or implied, or assumes any legal liability or responsibility for the accuracy, completeness, or usefulness of any information, apparatus, product, or process disclosed, or represents that its use would not infringe privately owned rights. Reference therein to any specific commercial product, process, or service by trade name, trademark, manufacturer, or otherwise does not necessarily constitute or imply its endorsement, recommendation, or favoring by the United States Government or any agency thereof. The views and opinions of authors expressed therein do not necessarily state or reflect those of the United States Government or any agency thereof. 


\section{Contents}

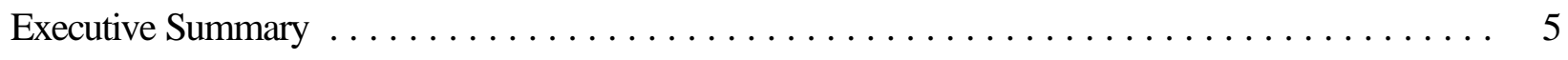

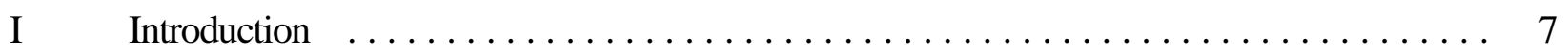

II Technical and Environmental Assessment $\ldots \ldots \ldots \ldots \ldots \ldots \ldots \ldots \ldots \ldots \ldots$

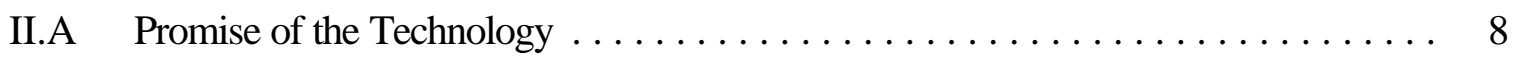

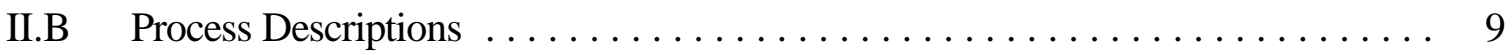

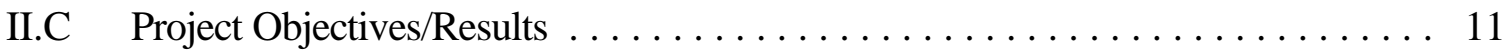

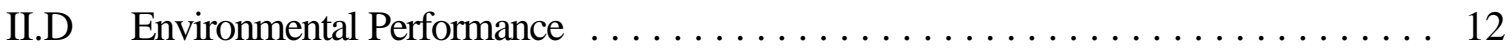

II.E Post-Demonstration Achievements $\ldots \ldots \ldots \ldots \ldots \ldots \ldots \ldots \ldots \ldots \ldots$

III Operating Capabilities Demonstrated $\ldots \ldots \ldots \ldots \ldots \ldots \ldots \ldots \ldots \ldots \ldots \ldots \ldots \ldots \ldots$

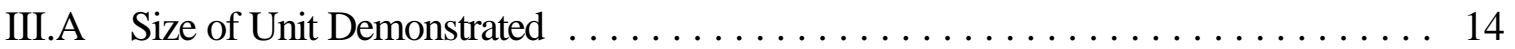

III.B Performance Level Demonstrated . . . . . . . . . . . . . . . . . . . 15

III.B.1 $\mathrm{SO}_{2}$ Emissions Reduction $\ldots \ldots \ldots \ldots \ldots \ldots \ldots \ldots \ldots \ldots \ldots \ldots$

III.B.2 $\mathrm{NO}_{\mathrm{X}}$ Emissions Reduction $\ldots \ldots \ldots \ldots \ldots \ldots \ldots \ldots \ldots \ldots \ldots \ldots$

III.B.3 Particulate Emissions Reduction $\ldots \ldots \ldots \ldots \ldots \ldots \ldots \ldots \ldots$

III.C Major Operating and Design Variables Studied $\ldots \ldots \ldots \ldots \ldots \ldots \ldots \ldots . \ldots \ldots$

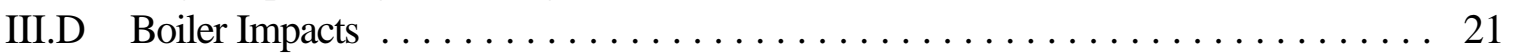

III.E Commercialization of the Technologies $\ldots \ldots \ldots \ldots \ldots \ldots \ldots \ldots \ldots \ldots 21$

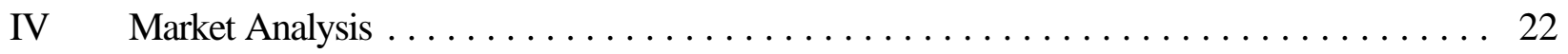

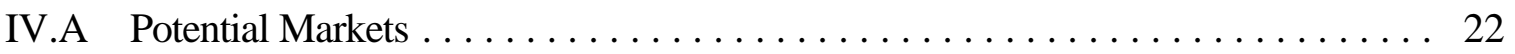

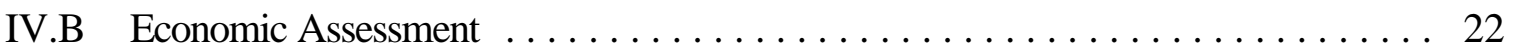

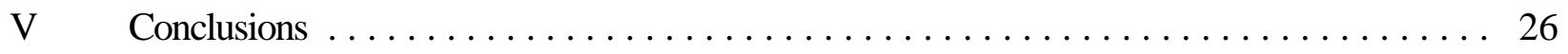

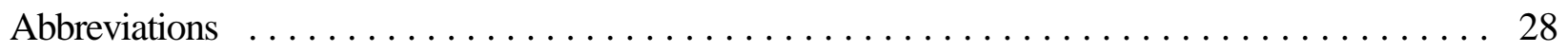

References .......................................... 29 


\section{List of Figures and Tables}

Figure

Page

1 Schematic Flowsheet of LIMB Process $\ldots \ldots \ldots \ldots \ldots \ldots \ldots \ldots \ldots \ldots$

2 Sorbent Injection Locations for LIMB Process $\ldots \ldots \ldots \ldots \ldots \ldots \ldots$

3 Schematic Flowsheet of Coolside Process $\ldots \ldots \ldots \ldots \ldots \ldots \ldots \ldots \ldots \ldots \ldots$

$4 \quad \mathrm{SO}_{2}$ Removal as a Function of $\mathrm{Ca} / \mathrm{S}$ Ratio in the LIMB Process $\ldots \ldots \ldots \ldots \ldots \ldots$

5 Effect of Humidification on $\mathrm{SO}_{2}$ Removal in the LIMB Process $\ldots \ldots \ldots \ldots \ldots$

$6 \quad \mathrm{SO}_{2}$ Removal as a Function of $\mathrm{Ca} / \mathrm{S}$ Ratio in the Coolside Process $\ldots \ldots \ldots \ldots$

$7 \quad \mathrm{SO}_{2}$ Removal as a Function of $\mathrm{Ca} / \mathrm{S}$ Ratio in the Coolside Process $\ldots \ldots \ldots \ldots$

8 Effect of Unit Size on Economics of LIMB, Coolside, and LSFO Processes $\ldots \ldots \ldots$. . . 24

Table

Page

1 Typical Coal Properties Used in Test Program $\ldots \ldots \ldots \ldots \ldots \ldots \ldots \ldots \ldots \ldots$

2 LIMB Performance at a $2.0 \mathrm{Ca}$ /S Ratio With Minimal Humidification $\ldots \ldots \ldots \ldots \ldots$

3 Economic Evaluation, 1992 Dollars $\ldots \ldots \ldots \ldots \ldots \ldots \ldots \ldots \ldots \ldots$

4 Economics of $\mathrm{SO}_{2}$ Removal $\ldots \ldots \ldots \ldots \ldots \ldots \ldots \ldots \ldots \ldots \ldots \ldots \ldots$ 


\section{Executive Summary}

This document serves as a U.S. Department of Energy (DOE) post-project assessment of a project in Round 1 of the Clean Coal Technology (CCT) Demonstration Program: LIMB Demonstration Project Extension and Coolside Demonstration. In 1987, the Babcock \& Wilcox (B\&W) Company agreed to extend a full-scale demonstration of the LIMB process and add the demonstration of the Coolside technology. Ohio Edison Company provided the host site. This project was funded by DOE, the State of Ohio Coal Development Office, B\&W, and Consolidation Coal Company (now known as CONSOL). DOE provided 39 percent of the total project cost of \$19.4 million. Ohio Edison Company provided in-kind contribution in the form of operations and routine maintenance.

Both processes involve flue gas desulfurization (FGD). LIMB uses furnace sorbent injection to remove sulfur dioxide $\left(\mathrm{SO}_{2}\right)$ and low nitrogen oxide $\left(\mathrm{NO}_{\mathrm{X}}\right)$ burners to reduce $\mathrm{NO}_{\mathrm{X}}$ emissions. The Coolside process uses duct sorbent injection to remove $\mathrm{SO}_{2}$. Both processes offer the potential for moderate FGD performance at what was projected to be relatively low cost in anticipation of the Clean Air Act Amendments of 1990 .

The Coolside demonstration was conducted between July 1989 and February 1990 and the LIMB Extension test program was conducted between April 1990 and August 1991. All tests were carried out on the 105 megawatt electric (MWe), coal-fired Unit 4 boiler at Ohio Edison's Edgewater Station in Lorain, Ohio.

The major performance objectives of this project were to:

C Demonstrate the applicability of the LIMB and Coolside technologies using a variety of coals.

C Achieve up to 70-percent reduction in $\mathrm{SO}_{2}$ emissions using either process.

C Determine the effects of process variables and sorbents on $\mathrm{SO}_{2}$ removal.

C Determine operability and reliability.

C Develop a database to design a commercial installation.

C Develop process economics.

These objectives were successfully met. With the LIMB process, up to 70-percent $\mathrm{SO}_{2}$ removal was achieved with high-sulfur coal, and the effects of coal sulfur content, sorbent type, injection level, and humidification on $\mathrm{SO}_{2}$ emissions were determined. $\mathrm{NO}_{\mathrm{X}}$ emissions were reduced by about 50 percent, meeting the limits for dry bottom wall-fired utility boilers under Title IV, Phase I of the Clean Air Act Amendments (CAAA) of 1990. Operability and reliability were excellent. Humidification of the flue gas was effective in maintaining particulate emission control performance of the ESP. 
Up to 70-percent $\mathrm{SO}_{2}$ removal was also achieved with the Coolside process, and short-term operability at a commercial scale was demonstrated. However, because the Coolside testing was limited, some operating and maintenance issues developed that could not be resolved during the test project.

Economic estimates prepared by $\mathrm{B} \& \mathrm{~W}$ indicate that LIMB is somewhat less expensive than Coolside. Both LIMB and Coolside appear to offer a cost benefit compared with limestone forced oxidation (LSFO), a conventional FGD process that achieves much higher levels of $\mathrm{SO}_{2}$ removal. However, the cost benefits of the LIMB and Coolside technologies have been somewhat eroded since newer, more favorable cost data on the LSFO process are now available. LIMB and Coolside might have applicability in specific instances where only moderate $\mathrm{SO}_{2}$ removal is required, but the economics are not currently favorable in the light of current market prices for $\mathrm{SO}_{2}$ allowances. 


\section{Introduction}

The goal of the U.S. Department of Energy (DOE) Clean Coal Technology (CCT) program is to furnish the energy marketplace with a number of advanced, more efficient, and environmentally responsible coal utilization technologies through demonstration projects. These projects seek to establish the commercial feasibility of the most promising advanced coal technologies that have already reached the proof-of-concept stage.

This document serves as a DOE post-project assessment of the CCT Round 1 project LIMB Demonstration Project Extension and Coolside Demonstration, described in a report to Congress (Babcock \& Wilcox 1987), a paper by DePero et al. (1992), and in a report by Goots et al. (1992). The original limestone injection multistage burner (LIMB) demonstration work was conducted by Babcock and Wilcox Company (B\&W) beginning in 1984, under the sponsorship of the U.S. Environmental Protection Agency (EPA) and the State of Ohio Coal Development Office (OCDO). In 1987, B\&W and the Ohio Edison Company agreed to extend the full-scale demonstration of LIMB technology under the sponsorship of DOE through its CCT Program, and with support from OCDO and Consolidation Coal Company, now known as CONSOL.

In a separate effort, CONSOL had been developing another flue gas desulfurization (FGD) technology known as the Coolside process. Both LIMB and Coolside use sorbent injection to remove $\mathrm{SO}_{2}$. The LIMB process injects the sorbent into the furnace and the Coolside injects the sorbent into the flue gas duct. In addition, $\mathrm{LIMB}$ uses low- $\mathrm{NO}_{\mathrm{X}}$ burners to reduce $\mathrm{NO}_{\mathrm{X}}$ emissions; hence it is categorized as a combination $\mathrm{SO}_{2} / \mathrm{NO}_{\mathrm{x}}$ control technology. To take advantage of synergism between the two processes, the CCT project was structured to incorporate demonstration of both the LIMB and Coolside processes.

Coolside testing was accomplished between July 1989 and February 1990, and the LIMB Extension test program was conducted between April 1990 and August 1991. The host site for both tests was the 105 MWe coal-fired Unit 4 at Ohio Edison's Edgewater Station in Lorain, Ohio.

The major performance objectives of this project were successfully achieved, with $\mathrm{SO}_{2}$ emissions reductions of up to 70 percent demonstrated in both processes. 


\section{Technical and Environmental Assessment}

\section{II.A Promise of the Technology}

This project was undertaken to extend the existing database on the LIMB process, developed under EPA sponsorship, to a broader range of coals and sorbents. Another incentive was to investigate the potential for increased $\mathrm{SO}_{2}$ capture by humidification of the flue gas, a technique incorporated in the Coolside process. Both processes involve sorbent injection, with LIMB using furnace sorbent injection while Coolside uses duct injection. The project was divided into two separate, but related, demonstrations of the technologies on the same boiler at Ohio Edison's Edgewater Station in Lorain, Ohio.

The LIMB process involves reducing emissions of two pollutants: $\mathrm{SO}_{2}$ by reaction with calcium-based sorbents and $\mathrm{NO}_{\mathrm{X}}$ by means of low- $\mathrm{NO}_{\mathrm{X}}$ burners. In early pilot work, limestone was injected into the upper furnace, along with the fuel, and the mixture is combusted in multi-stage (low- $\mathrm{NO}_{\mathrm{X}}$ ) burners giving rise to the acronym LIMB. The solid waste products are removed in an existing electrostatic precipitator (ESP) or baghouse. Although studied previously, furnace sorbent injection processes were of new interest in the late 1970s and early 1980s as a result of improved technology and the anticipation of what might be required for the Clean Air Act Amendments of 1990.

The encouraging results of previous EPA test work on LIMB led to the DOE CCT project discussed in this report, involving a full-scale demonstration at the Edgewater Station. In addition to limestone, other sorbents were tested, namely calcitic hydrated lime and calcitic hydrated lime doped with a small amount of calcium lignosulfate (referred to as ligno lime), while burning 3.0-percent sulfur Ohio coal. The LIMB CCT project provided the opportunity (1) to build upon previous work by incorporating a broader range of coals and sorbents, and (2) to evaluate the potential for increased $\mathrm{SO}_{2}$ capture through humidification of the flue gas. Although the earlier EPA work involved mixing sorbent with the feed coal, the technology studied in the CCT project used separate injection ports for the sorbent in the upper furnace where more favorable temperatures permitted improved removal.

The Coolside process, developed by CONSOL, injects sorbent into humidified flue gas downstream from the boiler between the air preheater and the electrostatic precipitator. One reason for combining the Coolside and LIMB processes in the CCT project was because of the common reliance on controlled humidification, which offered the potential for overcoming the deleterious effects of high resistivity ash on ESP performance. Both demonstrations were performed on the $105 \mathrm{MWe}$, wall-fired Unit 4 boiler at Ohio Edison's Edgewater Station in Lorain, Ohio. 


\section{II.B Process Descriptions}

The LIMB process injects a dry calcium-based sorbent into the upper furnace; hydrated lime $\mathrm{Ca}(\mathrm{OH})_{2}$ - was used in most for most of the testing. In general, lime is supplied as the hydrated form. Although some flowsheets for the process show a hydration step, this was not the case in the CCT project, nor is such a step reflected in the equipment list used for the cost estimate. $\mathrm{SO}_{2}$ capture takes place according to the following reactions:

$\begin{array}{ll}\text { Calcination: } & \mathrm{Ca}(\mathrm{OH})_{2}+\text { heat } 6 \mathrm{CaO}+\mathrm{H}_{2} \mathrm{O} \\ \text { Sulfation: } & \mathrm{CaO}+\mathrm{SO}_{2}+0.5 \mathrm{O}_{2} 6 \mathrm{CaSO}_{4}+\text { heat } \\ \text { Hydration: } & \mathrm{CaO}+\mathrm{H}_{2} \mathrm{O} 6 \mathrm{Ca}(\mathrm{OH})_{2}+\text { heat } \\ & \mathrm{CaSO}_{4}+2 \mathrm{H}_{2} \mathrm{O} 6 \mathrm{CaSO}_{4} \cdot 2 \mathrm{H}_{2} \mathrm{O}+\text { heat }\end{array}$

Effective mixing of the sorbent in the furnace chamber is necessary for good performance. The kinetics and thermodynamics of the individual reactions in relation to the time/temperature profiles in the furnace are also necessary for good performance. Calcination develops greater surface area for sulfation, while sintering of the particles is minimized by avoiding high temperature zones in the furnace. Since $\mathrm{CaSO}_{4}$ becomes thermodynamically unstable at temperatures above about 2,400 EF, sulfation takes place at lower flue gas temperatures. In addition, because of the mechanics of the humidification process, the water must cool the gas uniformly to minimize wall-wetting and resultant deposits. Figure 1 is a flowsheet of the LIMB process, and Figure 2 shows the location of the sorbent injection points.

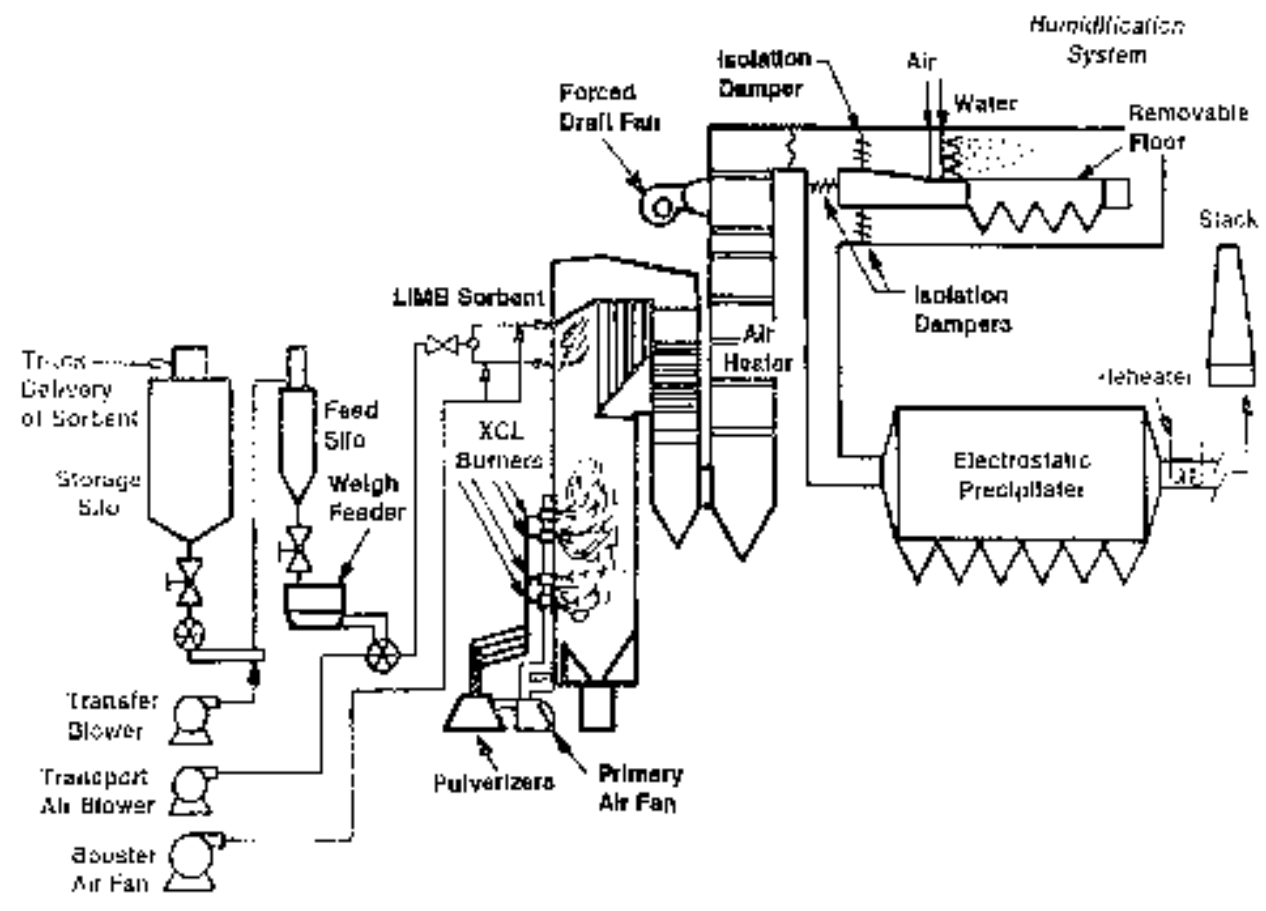

Figure 1. Schematic Flowsheet of LIMB Process 

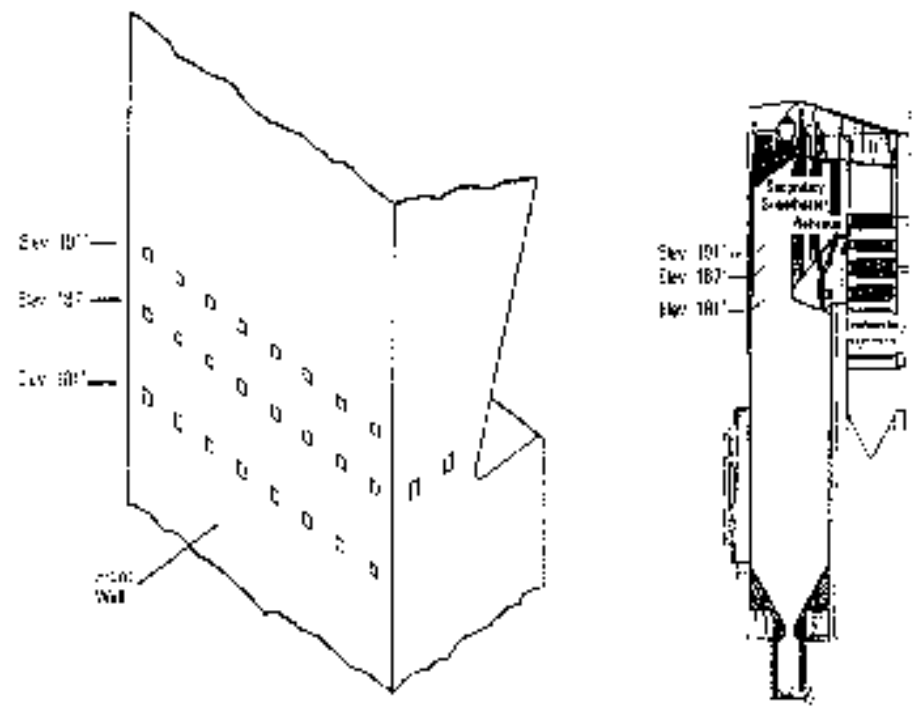

Figure 2. Sorbent Injection Locations for LIMB Process

In the Coolside process, the primary sorbent is hydrated lime. Because sodium salts can enhance $\mathrm{SO}_{2}$ removal, a small amount of sodium hydroxide - $\mathrm{NaOH}$ - was used as an additive. In a commercial installation, soda ash $-\mathrm{Na}_{2} \mathrm{CO}_{3}$ - would be the economical choice. Sorbent is injected into the flue gas duct between the air preheater and the ESP. Use of the additive also offers performance improvement because of the co-sorbent effect in capturing $\mathrm{SO}_{2}$. The primary reactions of lime with $\mathrm{SO}_{2}$ are the same as those in the LIMB process. The additional reactions involving $\mathrm{NaOH}$ are as follows:

$$
\begin{aligned}
& 2 \mathrm{NaOH}+\mathrm{SO}_{2} 6 \mathrm{Na}_{2} \mathrm{SO}_{3}+\mathrm{H}_{2} \mathrm{O}+\text { heat } \\
& 2 \mathrm{NaOH}+\mathrm{SO}_{2}+0.5 \mathrm{O}_{2} 6 \mathrm{Na}_{2} \mathrm{SO}_{4}+\mathrm{H}_{2} \mathrm{O}+\text { heat }
\end{aligned}
$$

The sulfur compounds are solids that are removed in the ESP. A flowsheet of the Coolside process is shown in Figure 3.

The basic difference with respect to $\mathrm{SO}_{2}$ capture between the LIMB and Coolside processes is the location of the sorbent injection point. The sorbent is injected into the upper furnace in the LIMB process, and the injection point is in the flue gas in the duct work between the air preheater and the ESP in the Coolside process. Low- $\mathrm{NO}_{\mathrm{X}}$ burners were also demonstrated independently in both the LIMB and Coolside demonstrations.

LIMB and Coolside were demonstrated at Ohio Edison's 105 MWe Edgewater Unit No. 4, fired with Ohio bituminous coal containing 1.2 to 3.0 percent sulfur. Since ash resistivity increases with the use of lime sorbents, humidification is incorporated into both processes to improve ESP performance. Humidification consists of injecting water into a chamber located within the flue gas duct upstream of the ESP. The humidification chamber is sized to provide residence time for complete evaporation of the water. 


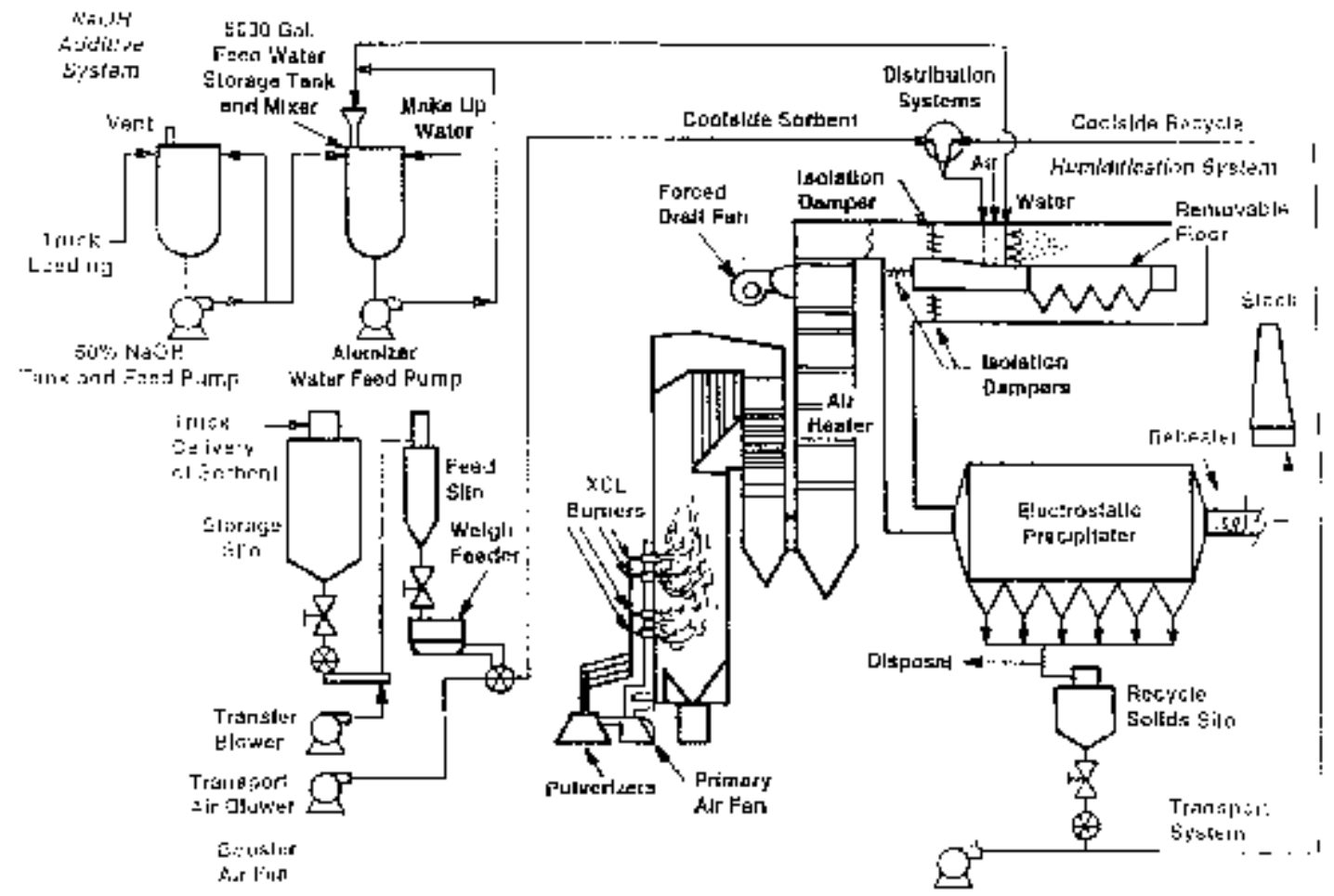

Figure 3. Schematic Flowsheet of Coolside Process

\section{II.C Project Objectives/Results}

There were six project objectives:

C Demonstrate the applicability of the LIMB and Coolside technologies using a variety of coals.

C Achieve up to 70-percent reduction in $\mathrm{SO}_{2}$ emissions using either technology.

C Determine effects of process variables and sorbents on $\mathrm{SO}_{2}$ removal.

C Determine operability and reliability.

C Develop a database to design a commercial installation.

C Develop process economics.

The applicability of LIMB technology was successfully demonstrated in the CCT project. Sulfur removal was studied with four different sorbents: calcitic hydrated lime, ligno lime, dolomitic lime, and calcitic limestone. One of the variables tested was sorbent feed rate, which determines the amount of 
calcium available to react with sulfur in the coal. The molar ratio of calcium to sulfur in the boiler is referred to as the $\mathrm{Ca} / \mathrm{S}$ stoichiometric ratio. Overall $\mathrm{SO}_{2}$ removal efficiencies were highest for ligno lime and calcitic hydrated lime at a $\mathrm{Ca} / \mathrm{S}$ ratio of 2.0 and minimal humidification. With maximum humidification, 70-percent $\mathrm{SO}_{2}$ reduction was achieved with both sorbents.

Operability and reliability of the LIMB process were excellent, with system availability of about 95 percent. Higher availability would be expected in a commercial system where operation is more stable. No major impact on overall system performance was noted because of sorbent injection. Determining the impacts on ESP performance resulting from particle size distribution, increase in resistivity of the ash, and increase in loading was beyond the scope of the project. However, humidification of the flue gas was found to be effective in maintaining a high level of particulate emission control in the ESP.

Operating problems encountered in the Coolside portion of the demonstration project included:

- Plugging of the vent system, resulting in intermittent feed problems.

- Deposition of solids on the atomizers in the humidification system.

- Erosion of the atomizers.

- Accumulation of solids in the humidification chamber

- Scaling of the outlet turning vanes and thermocouples in the humidifier

- Problems in controlling humidifier gas and liquid flows and temperatures

- Plugging in the solids recycle system.

- Solids buildup in the ESP.

Many of these operating problems have been resolved or the cause has been identified. Sorbent feed problems were overcome with a solids pump. Deposition on the atomizer airfoil assembly was solved by relocating additional points. Deposition on the nozzles themselves was aggravated by pushing the absolute limit of the design and sometimes beyond. Erosion of the atomizers was the result of running them longer than anticipated. A decision was made not to incur the cost of ceramic inserts used in commercial dry scrubbers that would have lasted longer.

\section{II.D Environmental Performance}

Both the LIMB and Coolside demonstrations had a beneficial impact on the environment in that they reduced $\mathrm{SO}_{2}$ emissions by up to 70 percent. In addition, the LIMB process reduced $\mathrm{NO}_{\mathrm{X}}$ emissions through the use of low- $\mathrm{NO}_{\mathrm{X}}$ burners from an uncontrolled level of 0.79 to $0.94 \mathrm{lb} / \mathrm{million}$ Btu to 0.44 $\mathrm{lb} /$ million Btu, representing a reduction of 44 to 53 percent. The controlled $\mathrm{NO}_{\mathrm{X}}$ emissions met the limits for dry bottom wall-fired utility boilers under Title IV, Phase I of the Clean Air Act Amendments (CAAA) of 1990. Both processes impacted ESP performance negatively because of the increased resistivity of the ash. Humidification was required to maintain particulate emission control within acceptable limits. Additional testing would be required to assess system impacts on ESP performance under a variety of conditions. 


\section{II.E Post-Demonstration Achievements}

The operability of the LIMB process was successfully demonstrated by the CCT project at Edgewater Station. Certain problems were experienced with ESP performance, but providing remedies was beyond the scope of the program. This technology would be commercially viable under certain plant size and coal sulfur content conditions. Depending on site-specific factors, LIMB could be a retrofit option for partial removal of $\mathrm{SO}_{2}$ from coal-fired plant flue gas. No additional work concerning the scope of this project has been done since completion of the CCT project.

Although the Coolside process was less fully developed than the LIMB process, the demonstration project met all the stated objectives. However, some operating problems were encountered. Most of these operating problems were connected with pushing too close to the approach to saturation temperature to achieve high $\mathrm{SO}_{2}$ removal. The economics of the Coolside process were found to be somewhat inferior to those of the LIMB process, which would impede implementation unless further work leads to improved performance and economics. The equipment is not in use because Edgewater Station has since been converted to operate on natural gas or \#2 distillate oil. 


\section{Operating Capabilities Demonstrated}

\section{III.A Size of Unit Demonstrated}

Both the LIMB Extension and Coolside Demonstration projects were conducted at Ohio Edison's Edgewater Station Unit 4 in Lorain, Ohio. This unit is a 105 MWe wall-fired utility boiler, first commissioned in 1957, which had been retrofitted with B\&W DRB-XCL® low-NO ${ }_{X}$ burners for the earlier EPA-sponsored project. The unit was further modified for the LIMB Extension project by adding a flue gas humidifier between the air preheater exit and the ESP inlet.

The LIMB Extension project burned coals having a nominal sulfur content of 1.6 to 3.8 percent, and the coal burned in the Coolside project had a nominal sulfur content of 2.8 to 3.0 percent. Analyses of the coals are given in Table 1.

Table 1. Typical Coal Properties Used in Test Program

\begin{tabular}{|l|c|c|c|}
\hline Coal Source & \multicolumn{3}{|c|}{ Coal Bituminous } \\
\hline Nominal Sulfur, \% & 3.8 & 3.0 & 1.8 \\
\hline Proximate Analysis, wt\% (dry basis) & & & \\
$\quad$ Fixed Carbon & 50.09 & 52.56 & 53.76 \\
Volatile Matter & 37.82 & 36.32 & 34.67 \\
Ash & $\underline{12.09}$ & $\underline{11.12}$ & $\underline{11.57}$ \\
Total & 100.00 & 100.00 & 100.00 \\
\hline Higher Heating Value & & & \\
Btu/lb & 12,825 & 12,960 & 12,942 \\
MJ/kg & 29.8 & 30.1 & 30.1 \\
\hline Ultimate Analysis, wt\% (dry basis) & & & \\
Carbon & 71.11 & 72.10 & 72.87 \\
Hydrogen & 4.83 & 4.89 & 4.78 \\
Sulfur & 3.44 & 2.56 & 1.45 \\
Nitrogen & 7.12 & 7.87 & 7.83 \\
Ash & 1.41 & 1.46 & 1.50 \\
Total & $\underline{12.09}$ & 11.12 & 11.57 \\
& 100.00 & 100.00 & 100.00 \\
\hline \hline
\end{tabular}




\section{III.B Performance Level Demonstrated}

\section{III.B.1 $\mathrm{SO}_{2}$ Emissions Reduction}

LIMB. Sulfur removal tests were performed with four different sorbents: calcitic hydrated lime, ligno lime, dolomitic lime, and calcitic limestone. Tests were initiated with ligno lime injected while burning nominal 3.0-percent sulfur coal. Coals with a nominal sulfur content of 1.6 and 3.8 percent were also tested. All combinations of sorbent and coals were tested with the exception of 3.8-percent sulfur coal with limestone. The effect of limestone particle size distribution was measured only with the 1.6percent sulfur coal.

A total of 289 LIMB tests was performed. A number of data points made up each test, with the minimum being three 10-minute averages of 10-second data, and the maximum being 71 10-minute averages of 10 -second data. The average was in excess of 3 hours of steady-state operation.

Maximum $\mathrm{SO}_{2}$ removal was approximately 60 percent with calcitic hydrated lime sorbent, minimal humidification, and a $2.0 \mathrm{Ca} / \mathrm{S}$ stoichiometric ratio. The performance with ligno lime was similar. Results with dolomitic lime indicated about 50-percent removal, while calcitic limestone removed between 20 and 40 percent, depending on particle size. An improvement of about 10-percent $\mathrm{SO}_{2}$ removal was observed when the flue gas was saturated to within a $20 \mathrm{EF}$ approach to the adiabatic saturation temperature. This improvement brought $\mathrm{SO}_{2}$ removal efficiency to 70 percent.

At the time of the original EPA LIMB demonstration that preceded the DOE LIMB Extension and Coolside demonstrations, low capital cost was more important than sorbent utilization. We know that both sorbent utilization and capital cost are important parameters in determining the cost associated with the LIMB or Coolside technology. The B\&W final report did not look into improved sorbent utilization. The CONSOL Coolside final report attempted to improve sorbent utilization by trying to recycle the sorbent.

Coolside. $\mathrm{SO}_{2}$ removal tests were performed using two primary sorbents, hydrated Lime A and hydrated Lime $\mathrm{G}$, with and without the addition of $\mathrm{NaOH}$ to the humidification water. $\mathrm{Na} / \mathrm{Ca}$ mol ratios were 0.17 to 0.24 . Both once-through and sorbent recycle tests were performed. Process tests were conducted over a 6.5 month period with round-the-clock testing performed for the last 4.5 months. The longest continuous run at $20 \mathrm{EF}$ temperature approach was 11 days.

Maximum $\mathrm{SO}_{2}$ removal was 70 percent with hydrated lime $\mathrm{A}$ using $\mathrm{NaOH}$ additive $(0.2 \mathrm{Na} / \mathrm{Ca}$ mol ratio), a nominal $20 \mathrm{EF}$ approach to saturation temperature, and a $\mathrm{Ca} / \mathrm{S}$ ratio of 2.0. Under the same conditions but with a $\mathrm{Ca} / \mathrm{S}$ ratio of 1.0 , the $\mathrm{SO}_{2}$ removal was 45 percent. In tests without the $\mathrm{NaOH}$ additive, the $\mathrm{SO}_{2}$ removal rates were about 35 percent at the $\mathrm{Ca} / \mathrm{S}$ ratio of 2.0.

Using the lower-cost hydrated Lime $\mathrm{G}$ sorbent, the maximum $\mathrm{SO}_{2}$ removal rates in once-through tests at a $25 \mathrm{EF}$ approach to saturation temperature with $\mathrm{NaOH}$ addition $(0.2 \mathrm{Na} / \mathrm{Ca}$ mol ratio $)$ were 
37 percent at $1.3 \mathrm{Ca} / \mathrm{S}$ and 55 percent at $1.9 \mathrm{Ca} / \mathrm{S}$. In tests without the additive, the removal rates were 29 percent at $1.4 \mathrm{Ca} / \mathrm{S}$ and 34 percent at $1.9 \mathrm{Ca} / \mathrm{S}$.

Removal efficiency decreased by 5 to 10 percent when the approach temperature was increased from 20 to $25 \mathrm{EF}$. Variations in approach to adiabatic saturation were not planned as part of the demonstration test program. However, difficulty in controlling the humidifier exit temperature and deterioration of humidifier performance during operation allowed this effect to be evaluated.

Sorbent utilization with Lime A decreased from about 30 to 37 percent at $1.3 \mathrm{Ca} / \mathrm{S}$ to about 28 to 30 percent at $2.3 \mathrm{Ca} / \mathrm{S}$. With Lime $\mathrm{G}$, sorbent utilization decreased from about 29 percent at $1.0 \mathrm{Ca} / \mathrm{S}$ to about 26 percent at $2.0 \mathrm{Ca} / \mathrm{S}$.

\section{III.B.2 $\mathrm{NO}_{\mathrm{X}}$ Emissions Reduction}

The first generation of B\&W's DRB-XCL® burners, which were installed as part of the initial EPAsponsored LIMB demonstration, were utilized in the LIMB Extension project. Uncontrolled $\mathrm{NO}_{\mathrm{X}}$ emissions prior to installation of the low- $\mathrm{NO}_{\mathrm{X}}$ burners were 0.79 to $0.94 \mathrm{lb} / \mathrm{million}$ Btu. Average $\mathrm{NO}_{\mathrm{X}}$ emissions during the testing were $0.44 \mathrm{lb} /$ million Btu, representing a 44 to 53 percent reduction. No consistent correlation was found between $\mathrm{NO}_{\mathrm{X}}$ emissions and load, oxygen concentration in the flue gas, carbon monoxide emissions, coal fineness, or pulverizers/burners in service.

During the Coolside test program, the same $\mathrm{B} \& \mathrm{~W}$ DRB-XCL® low-NO burners were utilized. $\mathrm{NO}_{\mathrm{X}}$ emissions averaged $0.48 \mathrm{lb} /$ million Btu, representing a 39 to 49 percent reduction from the uncontrolled level of 0.79 to $0.94 \mathrm{lb} /$ million Btu. The Coolside process had no apparent effect on $\mathrm{NO}_{\mathrm{X}}$ emissions; however, the Coolside project objectives did not include $\mathrm{NO}_{\mathrm{X}}$ testing or parametric evaluation of different variables or conditions.

\section{III.B.3 Particulate Emissions Reduction}

In the LIMB Extension Project, humidification of the flue gas was effective in maintaining particulate emission control performance of the ESP. Opacity was generally in the 2 to 5 percent range during injection of each of the sorbents. Opacity is regarded as a reasonable indication of particulate emissions associated with the LIMB process. Longer runs at steady-state conditions would have been required to define ESP performance more precisely, but were not planned as part of the project.

During Coolside process testing, the ESP operation gradually deteriorated with time. The cause was identified as buildup of emitter wire deposits as a result of pushing the operating temperatures to nearly the approach to saturation temperature and insufficient frame rapping to remove the deposits. The ESP specific collection area (SCA) was ample at 610; therefore, size was not the problem. Optimization of the ESP was not part of the goals for the Coolside test program, and additional evaluation would be required to identify causes and solutions for the ESP operating problems. 


\section{III.C Major Operating and Design Variables Studied}

The LIMB project studied the effects of several key operating variables on $\mathrm{SO}_{2}$ removal: coal sulfur (which determines $\mathrm{SO}_{2}$ concentration in the flue gas), sorbent choice, $\mathrm{Ca} / \mathrm{S}$ stoichiometric ratio, limestone particle size distribution, furnace injection level, and humidification. The results indicated that:

C $\mathrm{SO}_{2}$ removal efficiency increases with coal sulfur content. At a $\mathrm{Ca} / \mathrm{S}$ ratio of 2.0, approximately a 7-percent increase in removal efficiency was observed when the coal being fired changed from 1.6 to 3.8 percent sulfur. This effect is attributed to the increased driving force resulting from higher $\mathrm{SO}_{2}$ content of the flue gas.

C $\mathrm{SO}_{2}$ removal efficiency varies linearly with $\mathrm{Ca} / \mathrm{S}$ molar ratio, as shown in Figure 4. For ligno lime, removal efficiency increases from about 29 percent at $1.0 \mathrm{Ca} / \mathrm{S}$ to about 55 percent at $2.0 \mathrm{Ca} / \mathrm{S}$. These figures represent performance under minimum humidification conditions. The effect of humidification is discussed subsequently.

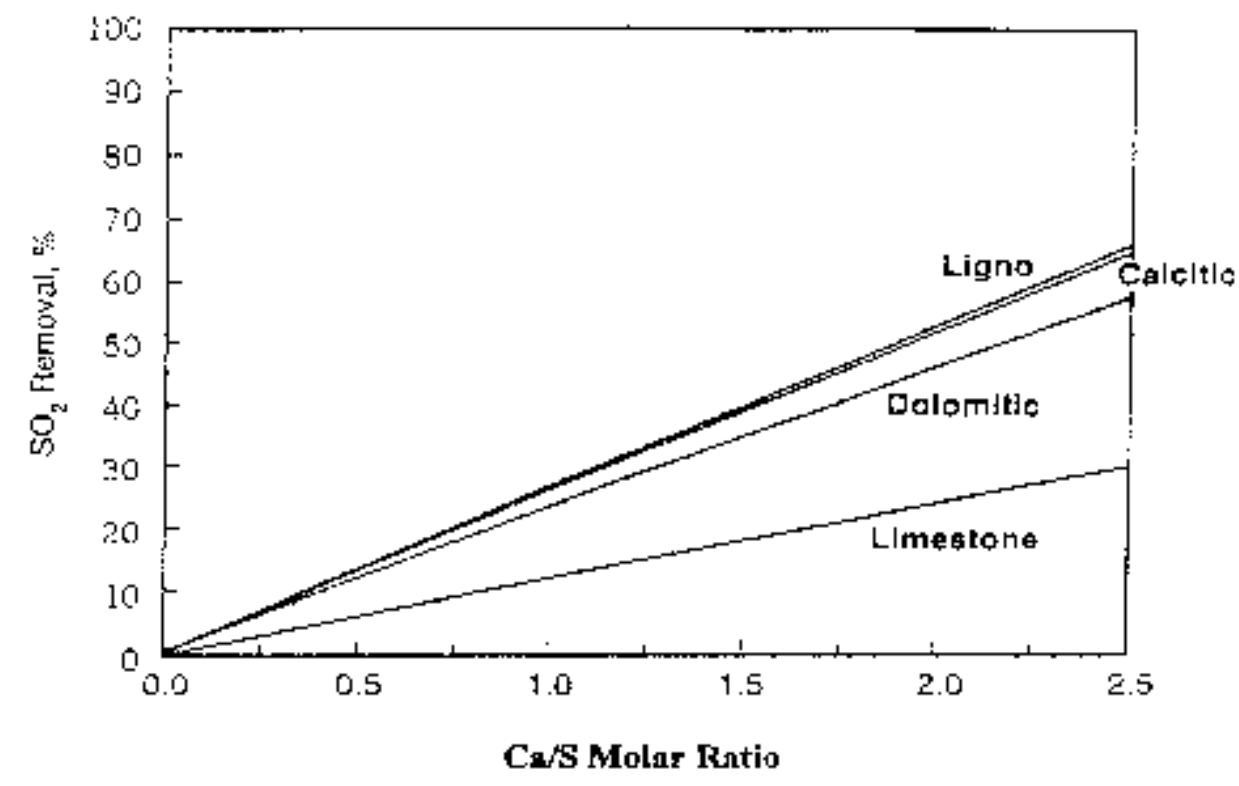

Figure 4. $\mathrm{SO}_{2}$ Removal as a Function of $\mathrm{Ca} / \mathrm{S}$ Ratio in the LIMB Process

C The most reactive sorbent tested was ligno lime. With a nominal coal sulfur content of 3.8 percent, $\mathrm{SO}_{2}$ removal efficiencies were 61 percent for ligno lime, 58 percent for calcitic lime, and 52 percent for dolomitic lime. Limestone was not tested with 3.8-percent sulfur coal, but demonstrated poor removal efficiency at the lower coal sulfur contents of 3.0 and 1.6 percent. The results are summarized in Table 2. 
Table 2. LIMB Performance at a 2.0 Ca/S Ratio With Minimal Humidification

\begin{tabular}{|l|c|c|c|}
\hline \multicolumn{5}{|c|}{ Nominal Coal Sulfur Content, wt $\%$} \\
\hline Sorbent & 3.8 & 3.0 & 1.6 \\
\hline \multicolumn{4}{|c|}{ SO $_{2}$ Removal Efficiency, \% } \\
\hline Ligno Lime & 61 & 63 & 53 \\
\hline Calcitic Lime & 58 & 55 & 51 \\
\hline Dolomitic Lime & 52 & 48 & 45 \\
\hline Limestone & -- & 25 & 22 \\
\hline
\end{tabular}

C In an attempt to improve the $\mathrm{SO}_{2}$ removal efficiency when using commercial, pulverized, calcitic limestone, a series of tests with varying particle sizes was performed. Increased $\mathrm{SO}_{2}$ removal was observed as the grind size decreased. Maximum removal was about 40 percent at a $\mathrm{Ca} / \mathrm{S}$ of 2.0 with a grind of 100 percent at $<10 \mathrm{Fm}$. Even if this relatively low $\mathrm{SO}_{2}$ removal were acceptable, this fine a grind would not be a viable alternative because of cost and handling considerations.

C Furnace injection levels were varied to determine the effects of temperature and mixing and dispersion of the sorbent at the point of injection. Previous studies had shown that maximum sorbent reactivity and sulfation are obtained in the temperature range of about 1,600 to $2,300 \mathrm{EF}$. The injectors were located where the temperature in the boiler is at the upper end of this range. Three plant elevations $(181,187$, and $191 \mathrm{ft})$ were chosen, with the 181 -ft elevation corresponding to the upper end of the sulfation temperature window at full load. The higher injection levels correspond to cooler temperatures.

Results were somewhat mixed, but indicated that injection at the highest temperature, corresponding to $181 \mathrm{ft}$, had the overall highest $\mathrm{SO}_{2}$ removal efficiency, with the 187 -ft elevation nearly as good. The cooler $191-\mathrm{ft}$ injection point yielded 2 to 3 percent lower removal efficiency at a $\mathrm{Ca} / \mathrm{S}$ of 2.0.

C Operating at a $20 \mathrm{EF}$ approach to adiabatic saturation temperature, achieved by humidification, resulted in a significant improvement in $\mathrm{SO}_{2}$ removal efficiency compared with minimum humidification. The most extensive tests were run using ligno lime injected at the 181-ft elevation while burning 1.6-percent sulfur coal. An improvement in removal efficiency of about 17 percent was observed at a $\mathrm{Ca} / \mathrm{S}$ ratio of 2.0. This effect is shown in Figure 5.

In the Coolside testing, the major design variables studied were $\mathrm{Ca} / \mathrm{S}$ ratio, $\mathrm{NaOH}$ additive, approach to adiabatic saturation temperature, different hydrated limes, and the secondary effects of $\mathrm{SO}_{2}$ concentration and temperature of the humidifier inlet gas. Tests were also performed to determine the capacity of recycled sorbent. Results of these experiments were as follows: 


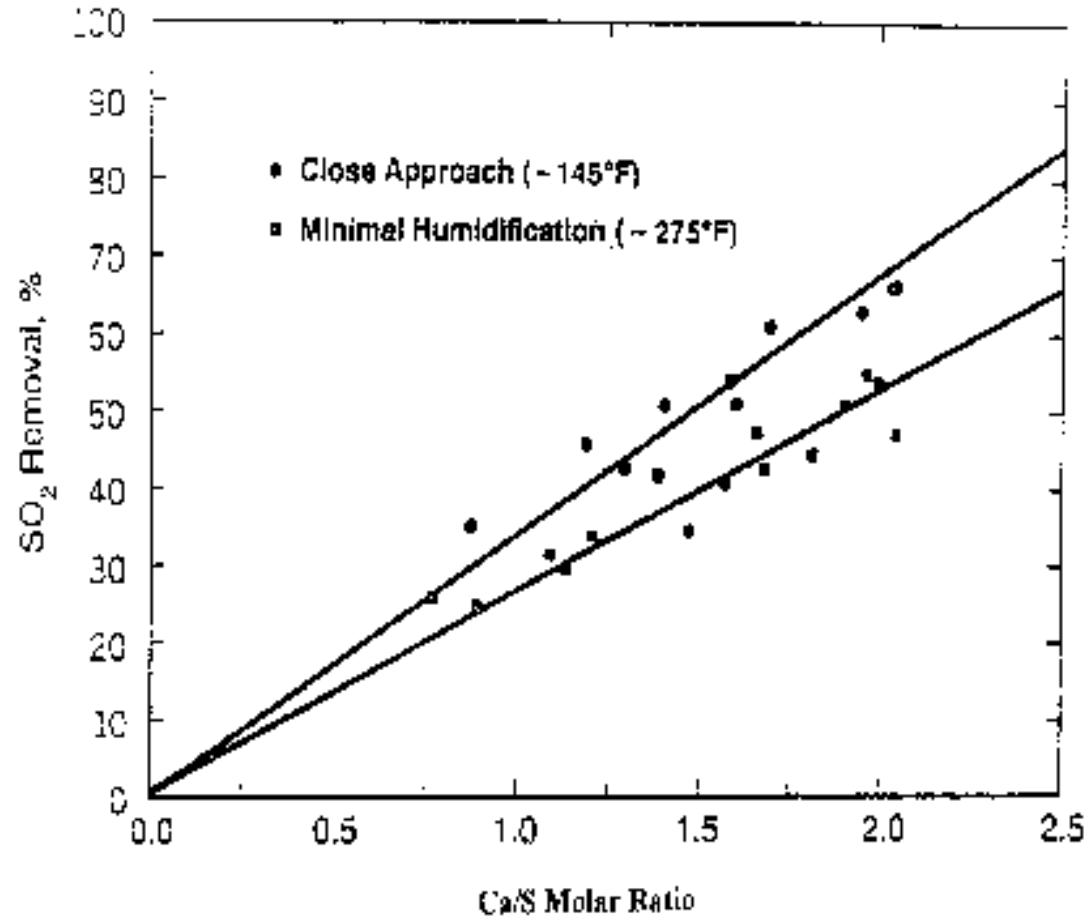

Figure 5. Effect of Humidification on $\mathrm{SO}_{2}$ Removal in the LIMB Process

C Effect of Ca/S Ratio. Figure 6 shows that when operating with hydrated Lime A, the $\mathrm{SO}_{2}$ removal efficiency increased linearly as the $\mathrm{Ca} / \mathrm{S}$ ratio was increased from 1.0 to 2.5 . Maximum removal efficiency increased from about 40 percent to over 70 percent with $\mathrm{NaOH}$ additive and a 19 to $22 \mathrm{EF}$ approach to saturation. Without the additive, the increase was from approximately 30 to 35 percent. Figure 7 shows a similar effect for hydrated Lime G, but the overall levels of $\mathrm{SO}_{2}$ removal efficiency were much lower.

C Effect of $\mathrm{NaOH}$ Additive. The addition of $\mathrm{NaOH}$ had a significant effect on $\mathrm{SO}_{2}$ removal and sorbent utilization. The sodium acts as a co-sorbent and promotes improved capture performance of the hydrated lime. Using hydrated Lime A at $2.0 \mathrm{Ca} / \mathrm{S}$ and 19 to $22 \mathrm{EF}$ temperature approach, $\mathrm{SO}_{2}$ removal averaged 70 percent with the sodium additive (at 0.17-0.24 Na/Ca molar ratio) and averaged 44 percent without the sodium additive - a 60 percent improvement in performance.

C Effect of Approach to Adiabatic Saturation Temperature. A linear decrease in $\mathrm{SO}_{2}$ removal efficiency was noted as the approach to saturation temperature increased from 19 to $32 \mathrm{EF}$. The decrease was from about 70 to 60 percent with hydrated Lime $\mathrm{A}$ and $\mathrm{Ca} / \mathrm{S}$ ratios of 1.8 to 2.2, and from 58 percent to approximately 38 percent with a $\mathrm{Ca} / \mathrm{S}$ of 1.2 to 1.6 . In both series, the $\mathrm{Na} / \mathrm{Ca}$ mol ratio was in the range of 0.17 to 0.24 . 


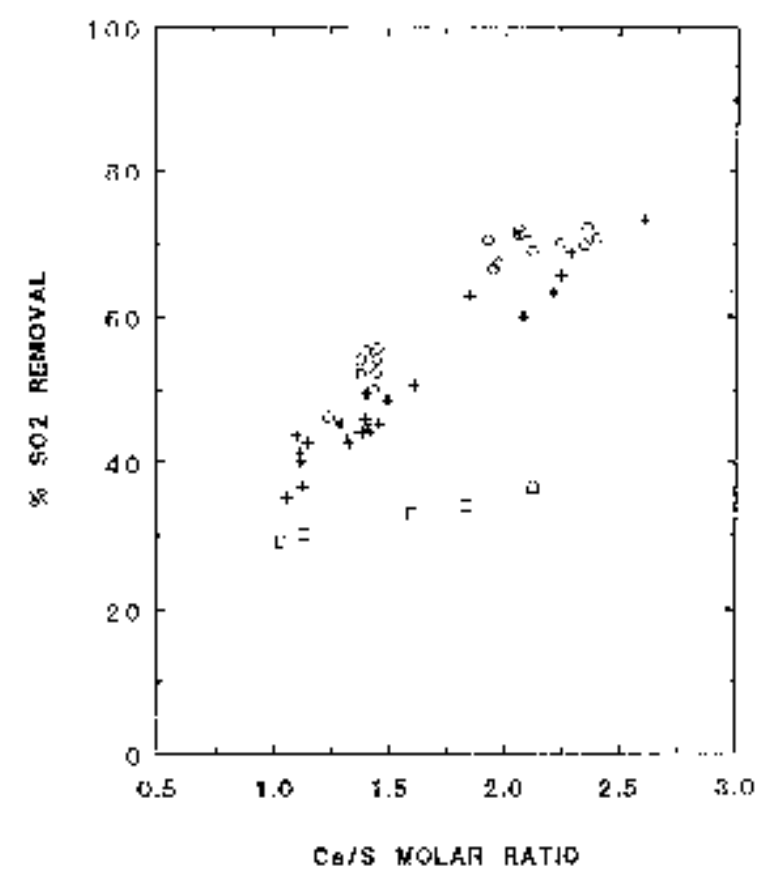

Circles $=0.17-0.24 \mathrm{Na} / \mathrm{Ca}, 19-22 \mathrm{EF}$ approach to adiabatic saturation temperature; Crosses $=0.17-0.24 \mathrm{Na} / \mathrm{Ca}$, 23-27 EF approach to saturation temperature; Squares = no $\mathrm{Na}$ approach to additive; $23-27 \mathrm{EF}$ to adiabatic saturation temperature

Figure 6. $\mathrm{SO}_{2}$ Removal as a Function of $\mathrm{Ca} / \mathrm{S}$ Ratio in the Coolside Process (Hydrated Lime A Sorbent)

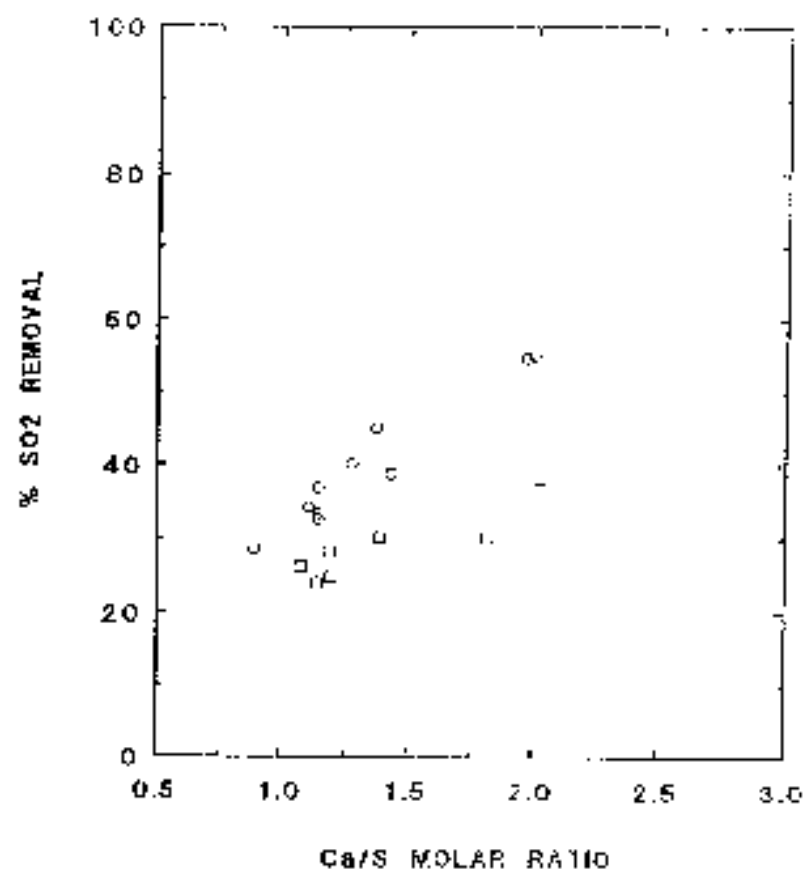

Circles $=0.17-0.24 \mathrm{Na} / \mathrm{Ca} 23-27 \mathrm{EF}$ approach to adiabatic temperature; Squares $=$ no NA additive; 23-27 EF approach to adiabatic temperature

Figure 7. $\mathrm{SO}_{2}$ Removal as a Function of $\mathrm{Ca} / \mathrm{S}$ Ratio in the Coolside Process (Hydrated Lime G Sorbent)

C Effect of Different Hydrated Limes. Two high-calcium hydrated limes were tested. Lime A had a higher $\mathrm{Ca}(\mathrm{OH})_{2}$ content $(92.97 \mathrm{wt} \%)$ and surface area $\left(23.2 \mathrm{~m}^{2} / \mathrm{g}\right)$ while Lime $\mathrm{G}$ had a $87.95 \mathrm{wt} \% \mathrm{Ca}(\mathrm{OH})_{2}$ content and a surface area of $16.7 \mathrm{~m}^{2} / \mathrm{g}$. Previous work indicated a correlation between sorbent surface area and $\mathrm{SO}_{2}$ removal efficiency. An absolute increase of 5 to 10 percent in $\mathrm{SO}_{2}$ removal was indicated with Lime A over Lime $\mathrm{G}$ when both were injected with $\mathrm{NaOH}$ additive. Without the additive, Lime A was only 1 to 3 percent better than Lime G.

C Other Variables Tested. Humidifier inlet gas $\mathrm{SO}_{2}$ concentration and humidifier inlet gas temperature were identified in pilot scale tests as secondary process variables that might affect $\mathrm{SO}_{2}$ removal. In the Edgewater tests of the Coolside process, observed $\mathrm{SO}_{2}$ removal was insensitive to either variable. A detailed statistical analysis did not indicate any significant effect.

C Other Effects. Coolside sorbent recycle and $\mathrm{SO}_{2}$ removal tests with some of the flue gas bypassing the humidifier were also performed near the conclusion of the program. Results indicated lower $\mathrm{SO}_{2}$ removal during bypass operation because a portion of the flue gas was not 
treated. Although sorbent recycle showed some capacity for additional $\mathrm{SO}_{2}$ capture, consistent operation of the recycle process was not achieved; additional tests would be required under controlled conditions to more fully evaluate the benefits of recycle.

\section{III.D Boiler Impacts}

In the LIMB project, sorbent injection into the furnace increased ash buildup on convective tube surfaces and hence reduced heat transfer. In most cases the material that did accumulate was easily removed by soot-blowing. The existing soot-blowing capability was not sufficient to handle the increased loading because of capacity problems, inadequate coverage of affected tube surface areas, or both. The soot-blowing system was upgraded in an effort to improve performance of the reheat and primary superheat banks of the convective pass. Future LIMB applications would have to address both the capacity and coverage of an existing or expanded soot-blower system.

The Coolside project had no effect on boiler performance because it involved only post-combustion treatment of the flue gas.

\section{III.E Commercialization of the Technologies}

Neither the LIMB nor the Coolside process has been placed in commercial operation. This is consistent with the current trend in the United States in which approaches other than FGD are being used to meet the problem of $\mathrm{SO}_{2}$ emissions. Relatively few of the plants regulated under Phase I of the 1990 CAAA have installed scrubbers for $\mathrm{SO}_{2}$ control. A large proportion of these plants have achieved compliance by fuel switching or by purchasing $\mathrm{SO}_{2}$ emission credits. Based on the current low market price for $\mathrm{SO}_{2}$ allowances, this trend is likely to continue in Phase II. The LIMB and Coolside equipment used in the CCT project are no longer in use; the Edgewater Station has been converted to natural-gas-fired or \#2 distillate-oil-fired power generation. 


\section{Market Analysis}

\section{IV.A Potential Markets}

The LIMB and Coolside processes are primarily applicable for retrofitting in existing boilers. Applications do not depend on boiler type, age, size, or type and sulfur content of the coal burned. Whereas conventional wet scrubbers now are designed to remove at least 95 percent of the $\mathrm{SO}_{2}$ in the flue gas, the LIMB and Coolside processes remove about 70 percent maximum. The latter technologies are thus more suited to situations where limited $\mathrm{SO}_{2}$ removal is required.

The acid rain provisions of the 1990 CAAA give utilities the option to select the most cost-effective approach to controlling $\mathrm{SO}_{2}$ emissions to the required levels. In situations requiring only limited $\mathrm{SO}_{2}$ removal, there could be a number of candidate plants in the United States suitable for either the LIMB or Coolside process. The LIMB process could obtain a sizeable share of the sorbent injection technologies market because of cost competitiveness in certain applications and, in addition, because it offers concurrent reduction in $\mathrm{NO}_{\mathrm{X}}$ emissions. The Coolside process could also have a role to play in this market if necessary process improvements were made.

Competing technologies are those that also have limited $\mathrm{SO}_{2}$ removal capability. Like the LIMB and Coolside processes, these technologies fall under the broad category of sorbent injection, which includes duct sorbent injection (DSI), limestone injected into the furnace with activation of untreated calcium oxide (LIFAC), and confined zone dispersion (CZD). Comparative performance and costs would determine site-specific applications.

However, the present major approaches to CAAA compliance in the United States are (1) purchasing $\mathrm{SO}_{2}$ emissions allowances, or (2) switching to low-sulfur coals. It is not clear what role will be played by processes offering only partial removal of $\mathrm{SO}_{2}$.

\section{IV.B Economic Assessment}

The B\&W final report (Goots et al. 1992) includes projected commercial-scale economics for the LIMB and Coolside technologies as well as a conventional limestone forced oxidation (LSFO) FGD process. The economic evaluation, which uses the Technical Assessment Guide (TAG ${ }^{\mathrm{TM}}$ ) methodology developed by the Electric Power Research Institute (1989), is based on design and operating experience from the LIMB CCT project, CONSOL's topical report (McCoy et al. 1992) on the Coolside process, and a comprehensive review of state-of-the-art wet limestone FGD systems.

Both the LIMB and Coolside evaluations assume optimized commercial systems utilizing hydrated calcitic lime as the sorbent. $\mathrm{SO}_{2}$ removal efficiencies are assumed to be 60-percent removal with the LIMB process (although 70-percent removal was demonstrated in the CCT project) and 70-percent 
removal with the Coolside process. The LSFO system assumes a typical commercial process utilizing limestone to achieve 95-percent $\mathrm{SO}_{2}$ removal. Although the LIMB process also reduces $\mathrm{NO}_{\mathrm{X}}$ emissions through the use of low- $\mathrm{NO}_{\mathrm{X}}$ burners, no credit for $\mathrm{NO}_{\mathrm{X}}$ removal is used in the economic evaluation.

Reference plants are assumed to burn 1.5, 2.5, and 3.5 percent sulfur coal in units of 100, 150, 250, and 500 MWe capacity. In addition, economic sensitivities to capacity factor, book life, and reagent cost are determined. Reagent costs are assumed to be \$64/ton for lime, both dolomitic and hydrated calcitic, and \$15/ton for limestone. Table 3 gives a summary of the base case economics for the three processes. Since the B\&W report does not present details of the levelized cost calculations, Table 4 gives only the total $\$$ ton of $\mathrm{SO}_{2}$ removed for each technology. The relative contributions of capital charge and operation and maintenance $(\mathrm{O} \& \mathrm{M})$ expenses to the levelized cost are not available.

Table 3. Economic Evaluation, 1992 Dollars

\begin{tabular}{|c|c|c|c|}
\hline FGD Process & LIMB & Coolside & LSFO \\
\hline $\begin{array}{l}\text { Coal Properties } \\
\text { Higher Heating Value (HHV), Btu/lb }\end{array}$ & 11,872 & 11,872 & 11,872 \\
\hline $\begin{array}{l}\text { Power Plant Attributes With Controls } \\
\text { Plant Capacity (net), MWe } \\
\text { Power Produced (net), } 10^{9} \mathrm{kWh} / \mathrm{yr} \\
\text { Capacity Factor, } \% \\
\text { Coal Sulfur Content, wt } \%\end{array}$ & $\begin{array}{c}500 \\
2.85 \\
65 \\
2.5\end{array}$ & $\begin{array}{c}500 \\
2.85 \\
65 \\
2.5\end{array}$ & $\begin{array}{c}500 \\
2.85 \\
65 \\
2.5\end{array}$ \\
\hline $\begin{array}{l}\mathbf{S O}_{2} \text { Emissions Control Data } \\
\text { Removal Efficiency, \% } \\
\text { Sorbent Ratio (mol } / \mathrm{mol}), \mathrm{Ca} / \mathrm{S} \text { inlet } \\
\text { Sorbent Ratio }(\mathrm{mol} / \mathrm{mol}), \mathrm{Ca} / \mathrm{S} \text { removed } \\
\text { Additive Ratio }(\mathrm{mol} / \mathrm{mol}), \mathrm{Na} / \mathrm{Ca}\end{array}$ & $\begin{array}{l}60 \\
2.0 \\
-- \\
--\end{array}$ & $\begin{array}{l}70 \\
2.0 \\
-- \\
0.2\end{array}$ & $\begin{array}{l}95 \\
-- \\
2.0 \\
--\end{array}$ \\
\hline Total Capital Requirement, $\$ / \mathrm{kW}$ & 36 & 76 & 169 \\
\hline Levelized Cost $\mathbf{t}^{\mathrm{a}}, \$ /$ ton $\mathrm{SO}_{2}$ removed & 416 & 502 & 411 \\
\hline
\end{tabular}

${ }^{\mathrm{a}}$ Assumes a 15-year project life, constant dollar analysis. Includes capital charge and O\&M expense.

Table 4. Economics of $\mathrm{SO}_{2}$ Removal

\begin{tabular}{|l|c|c|c|}
\hline Technology & LIMB & Coolside & LSFO \\
\hline Total Capital, $\$ / \mathrm{kW}$ & 36 & 76 & 169 \\
\hline Levelized Cost, $\$$ /ton $\mathrm{SO}_{2}$ removed & 416 & 502 & 411 \\
\hline
\end{tabular}


Although sorbent utilization is a significant factor in the economics because of the direct effect on sorbent consumption and hence operating cost, this variable was not addressed in the B\&W economics. As indicated previously, sorbent utilization is quantified and discussed in CONSOL's final report on the Coolside process (McCoy et al. 1992), but it is not mentioned in B\&W's final report on the LIMB process (1987). However, even the Coolside economics do not provide sufficient breakdown to show the contribution of sorbent cost to total process cost, although one figure shows the effect of sorbent price on the economics.

The capital cost of either the LIMB or Coolside process appears to be significantly lower than that of the LSFO process. Recent process developments have resulted in significantly lower capital and O\&M costs for the LSFO process than those used in the B\&W economic analysis. If the comparison were updated, these process developments would need to be included. It would also be useful to compare the LIMB and Coolside processes with other options such as the DSI, CZD, and LIFAC processes. None of these partial $\mathrm{SO}_{2}$ removal processes would be economically competitive in today's market where $\mathrm{SO}_{2}$ allowances can be purchased for as little as $\$ 100$ to 150/ton.

Figure 8 shows levelized cost as a function of plant capacity for each of the three processes, assuming coal with a 2.5 -percent sulfur content and a 65-percent capacity factor.

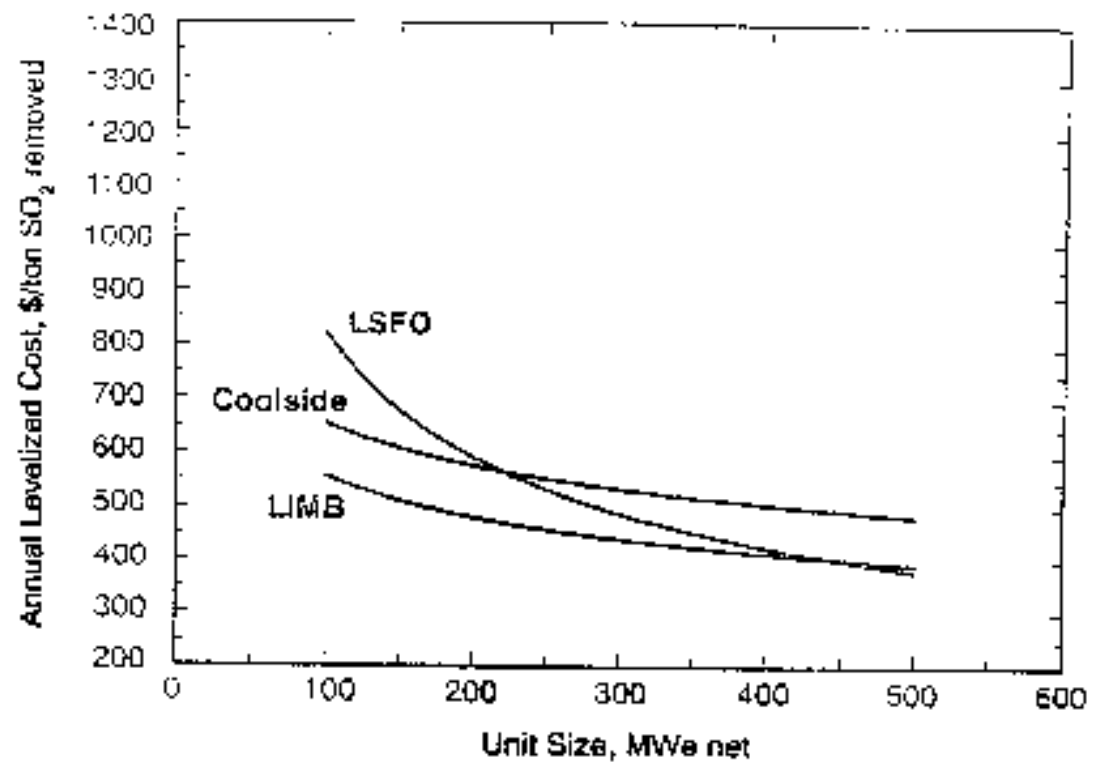

Figure 8. Effect of Unit Size on Economics of LIMB, Coolside, and LSFO Processes

(2.5\% sulfur coal, $65 \%$ capacity factor)

The B\&W report (1987) includes similar graphs for other coal sulfur contents and other capacity factors. The LIMB process is economically favored over the LSFO process for all unit sizes while burning 1.5-percent sulfur coal, for those up to $450 \mathrm{MWe}$ while burning 2.5-percent sulfur coal, and for 
those up to 240 MWe while burning 3.5-percent sulfur coal. The Coolside process is favored over the LSFO process for sizes up to 500 MWe burning 1.5-percent sulfur coal and for units up to $100 \mathrm{MWe}$ burning 3.5-percent sulfur coal. In all cases, LIMB process economics are more favorable than those of the Coolside process primarily because of the need to achieve a close approach to saturation in the humidification process.

Additional sensitivity studies show that lower plant capacity factor favors the LIMB and Coolside processes, as does shorter book life. Reagent cost variation has more impact on the LIMB and Coolside processes than on the LSFO process. This suggests that if further work were to be done on the LIMB and Coolside processes, it should focus on improving sorbent utilization. 


\section{Conclusions}

\section{LIMB}

C Reductions in $\mathrm{SO}_{2}$ emissions of up to 70 percent can be achieved using the most reactive sorbent (ligno lime), an optimum stoichiometric ratio (2.0), and humidification of the flue gas to a $20 \mathrm{EF}$ approach to saturation temperature.

C $\mathrm{NO}_{\mathrm{X}}$ emissions are reduced by about 50 percent through the use of low- $\mathrm{NO}_{\mathrm{X}}$ burners.

C Calcitic limes are more effective for $\mathrm{SO}_{2}$ removal than the type-"N" dolomitic lime tested on a $\mathrm{Ca} / \mathrm{S}$ basis, and calcitic limestone had the lowest $\mathrm{SO}_{2}$ removal of the sorbents tested.

C Ligno lime offers the greatest reduction in $\mathrm{SO}_{2}$ but has only a slight advantage over the commercial hydrated calcitic lime from which it is made. Economic factors would probably determine which sorbent is utilized in any specific application.

C Proper mixing and dispersion of the injected sorbent into the temperature window required for maximum removal are more important than finding the optimum injection level or temperature.

C Humidification of the flue gas to within $20 \mathrm{EF}$ of its adiabatic saturation temperature provides a 10-percent increase in $\mathrm{SO}_{2}$ removal for all sorbents tested.

C ESP performance is maintained with minimal humidification.

C No substantial deposits adhered on tube surfaces during the demonstration. Soot-blowing was effective in removing any ash that did accumulate.

\section{Coolside}

C $\quad \mathrm{SO}_{2}$ removal rates of 70 percent can be achieved while burning 3-percent sulfur coal, using commercial hydrated lime with $\mathrm{NaOH}$ additive at a $\mathrm{Na} / \mathrm{Ca}$ molar ratio of about 0.20 .

C Short-term operability of the system was demonstrated with 11-day steady-state runs under nominal conditions, commercial plants are expected to have many of these problems solved that were encountered during demonstration. To achieve reliability for utility application would require some design modifications.

The economic estimates given in Table 3 indicate that the LIMB process has a levelized cost benefit over the LSFO process, a conventional FGD process that achieves higher levels of $\mathrm{SO}_{2}$ 
removal. This comparison is now out of date since newer, lower-cost LSFO processes are available. The Coolside process appears to be somewhat more expensive than the LIMB process.

However, neither process is competitive in the current market. These technologies, which achieve only partial $\mathrm{SO}_{2}$ removal, may at best represent a niche market in the United States and other countries.

This would need to be explored in greater depth in light of increasingly stringent air pollution regulations. 


\section{Abbreviations}

B\&W Black and Wilcox Company

CAAA Clean Air Act Amendments of 1990

$\mathrm{CaO}$ quicklime

$\mathrm{Ca}\left(\mathrm{OH}_{2}\right)$ hydrated lime

$\mathrm{CaSO}_{2}$ calcium sulfate

CCT clean coal technology

CONSOL Consolidation Coal Company

CZD confined zone dispersion

DOE U.S. Department of Energy

DSI duct sorbent injection

EPA U.S. Environmental Protection Agency

ESP electrostatic precipitation

FGD flue gas desulfurization

HHV higher heating value

LIFAC limestone injection with activation of untreated calcium oxide

LIMB limestone injection multistage burner

LSFO limestone forced oxidation

MWe megawatt electric

$\mathrm{Na}_{2} \mathrm{CO}_{3}$ soda ash

$\mathrm{NaOH}$ sodium hydroxide

$\mathbf{N O}_{\mathbf{X}} \quad$ nitrogen oxides

O\&M operation and maintenance

OCDO Ohio Coal Development Office

SCA specific collection area

$\mathrm{SO}_{2}$ sulfur dioxide 


\section{References}

Babcock \& Wilcox Company, 1987. LIMB Demonstration Project Extension, Comprehensive Report to Congress, DOE Clean Coal Technology Program, Babcock \& Wilcox Company.

DePero, M.J., et al. 1992. Final Results of the DOE LIMB and Coolside Demonstration Projects, Babcock \& Wilcox Company, presented at First Annual Clean Coal Technology Conference, Cleveland, OH, November 1992.

Electric Power Research Institute. 1989. TAG TM Technical Assessment Guide, Report P-6587-1, Electric Power Research Institute: Palo Alto, CA.

Goots, T.R., et al. 1992. LIMB Demonstration Project Extension and Coolside Demonstration Final Report, Babcock \& Wilcox Company.

McCoy, D.C., et al. 1992. The Edgewater Coolside Process Demonstration: A Topical Report, report to Babcock \& Wilcox Company, Consolidation Coal Company. 